\section{India blocks panel hearings on impact of dam construction}

[NEW DELHI] The Indian government has stirred up controversy by withdrawing permission at the last minute for the Cape Town-based independent World Commission on Dams (WCD) to hold a set of public hearings in India on large dams. The meeting will now be held in Cape Town.

The WCD was formed in February at the initiative of the World Bank and the World Conservation Union. It aims to start a dialogue on developing dams that will have minimal environmental impact. Its worldwide membership includes governments, nongovernment environmentalist groups and indigenous people's organizations.

The Indian hearings were to have been the first in a series around the world aimed at developing a set of guidelines for the planning, design and construction of environmentally safe dams.

Having obtained government clearance, the commission had scheduled Indian hearings in Bhopal and New Delhi this week (19-23 September). But on 11 September, WCD chairman Kader Asmal, South Africa's minister for water resources and forestry, was told that it was not an "opportune" time to visit India to conduct the hearings.

Indian officials say the government asked the commission to "postpone" its visit, as it did not want the WCD hearings to interfere with a legal case over the Sardar Sarovar dam project which is due before the Indian supreme court later this month.

The massive dam across the River Narmada has been embroiled in bitter controversy for several years between the Gujarat government, which is building the dam, and environmental and human-rights activists. These are led by sociologist and WCD member Medha Patkar of Narmada Bachao Andolan (Save Narmada), which claims that the Gujarat government has resettled only 4,500 of the 120,000 people displaced by the dam.

A promise by the commission that the hearings would exclude reference to the Narmada dam project has not persuaded New Delhi to alter its stand.

Patkar has alleged that the Indian government cancelled the WCD's visit under pressure from Gujarat politicians who believe the commission consists mainly of anti-dam activists. Two weeks ago, the Gujarat state legislature passed a resolution describing the WCD's proposed visit as "an intrusion into our internal affairs".

But according to Asmal, the commission seeks to bring "a more responsible approach to investments in large dam projects" by conducting a comprehensive review of their costs and benefits.

K.S. Jayaraman

\title{
Edgy Japan wants a new reconnaissance satellite
}

[TOKYO] Japan is looking into launching a reconnaissance satellite to improve its ability to gather security information. The move comes despite a long-standing parliamentary resolution criticizing the 'militarization' of space, and follows last month's firing of a North Korean missile over Japanese territory into the Pacific Ocean.

Fears that North Korea had test-launched a three-stage ballistic missile on 31 August put Japan on a high-security alert. North Korea says it was actually launching a 'singing satellite' for peaceful purposes such as broadcasting patriotic songs in praise of 'dear leader' Kim Jong-il. It is believed to have used a multi-stage missile with an estimated range of 2,000 kilometres.

The US State Department last week concluded that the suspected third stage of a missile actually was a small satellite, but that it failed to achieve orbit. Even if it was, Japan still views North Korea's action - firing a long-range missile over Japan without warning - as a threat to its security.

The Japanese government responded by freezing various aid packages, including 135 billion yen (US\$ 1 billion) for an international project to build light-water reactors in North Korea. The project, carried out under the auspices of the Korean Peninsular Energy Development Organization, started in 1994 and was meant to stop North Korea pursuing its suspected nuclear weapons programme.

The rocket launch led Japan's ruling Liberal Democratic Party (LDP) to set up a working group to discuss the introduction of a multi-purpose satellite system with reconnaissance capabilities.

"We have instructed the ministries and agencies concerned to study types of satellite systems suitable for carrying out reconnaissance activities," said Prime Minister Keizo Obuchi at a recent LDP meeting in Tokyo.

Particular attention has been given to the National Space Development Agency's Advanced Land Observation Satellite (ALOS), scheduled for launch in 2003 to carry out a mapping, regional observation, disaster observation and earth resources survey. Ironically, ALOS, which was originally called the High-Resolution Land Observation Satellite, changed its name after the agency thought it sounded like a reconnaissance satellite with military purposes.

"Although we are obtaining information from all space-related sources under the respective ministries and agencies, the technology obtained through the development of ALOS would certainly be a great advantage for planning a possible model for Japan's reconnaissance satellite," says Hideo Fun-

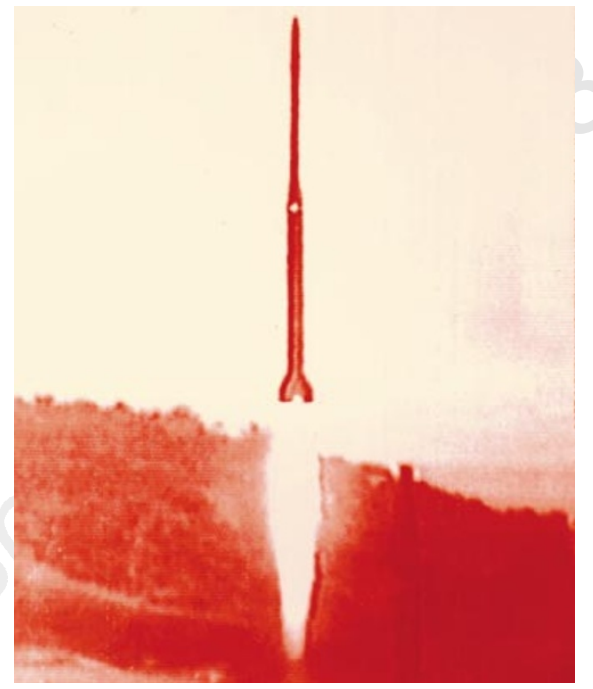

Hit or missile: was the North Korean rocket that buzzed Japan just trying to spread some music?

abashi, who is responsible for space research at the Science and Technology Agency (STA).

The United States is willing to cooperate in the development of such satellites. "It is still not known whether the cooperation would be at the technical level, but there will certainly be an exchange of information," says Funabashi.

The main sticking point could be a resolution passed by the Diet (Japan's parliament) in 1969 on the non-militarization of space. But unusually strong support from opposition parties, including the LDP's main rival the Democratic Party of Japan, may ease some of its restrictions.

As a result of a bilateral security meeting in New York last Sunday (20 September), Japan and the United States have agreed to begin joint research on the TMD system - a comprehensive defence system for intercepting ballistic missiles - which they have been discussing since 1993 when North Korea test-fired a missile into the Sea of Japan.

Japan is expected to begin the collaboration in the fiscal year 1999, which starts in April. Parliamentary approval for the project, and the allocation of an additional budget estimated at $¥ 5$ - $¥ 10$ billion, is expected to be made official by the end of this year. But the main cost of the project is expected to be between $¥ 20$ billion and $¥ 30$ billion for the five-year period, which is causing concern given Japan's poor economic prospects.

There is also anxiety about instability in the Defence Agency, which has been rocked by a financial scandal. Agency officials added insult to injury by trying to dispose of documents related to the scandal amid the chaos following the missile launch. AsakoSaegusa 